\title{
State Clean Energy Practices: Renewable Portfolio Standards
}

Technical Report NREL/TP-670-43512 July 2008

David Hurlbut 


\section{State Clean Energy Practices: Renewable Portfolio Standards}

David Hurlbut

Prepared under Task No. IGST.8300

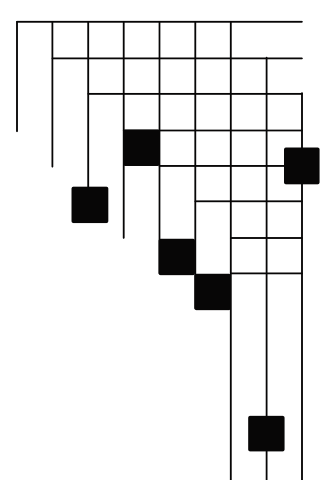




\section{NOTICE}

This report was prepared as an account of work sponsored by an agency of the United States government. Neither the United States government nor any agency thereof, nor any of their employees, makes any warranty, express or implied, or assumes any legal liability or responsibility for the accuracy, completeness, or usefulness of any information, apparatus, product, or process disclosed, or represents that its use would not infringe privately owned rights. Reference herein to any specific commercial product, process, or service by trade name, trademark, manufacturer, or otherwise does not necessarily constitute or imply its endorsement, recommendation, or favoring by the United States government or any agency thereof. The views and opinions of authors expressed herein do not necessarily state or reflect those of the United States government or any agency thereof.

Available electronically at http://www.osti.gov/bridge

Available for a processing fee to U.S. Department of Energy and its contractors, in paper, from:

U.S. Department of Energy

Office of Scientific and Technical Information

P.O. Box 62

Oak Ridge, TN 37831-0062

phone: 865.576 .8401

fax: 865.576 .5728

email: mailto:reports@adonis.osti.gov

Available for sale to the public, in paper, from:

U.S. Department of Commerce

National Technical Information Service

5285 Port Royal Road

Springfield, VA 22161

phone: 800.553 .6847

fax: 703.605.6900

email: orders@ntis.fedworld.gov

online ordering: http://www.ntis.gov/ordering.htm 


\section{Table of Contents}

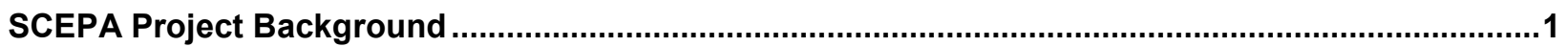

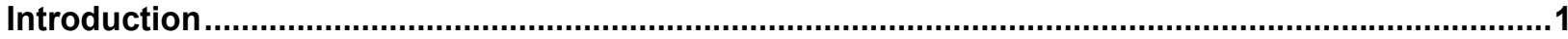

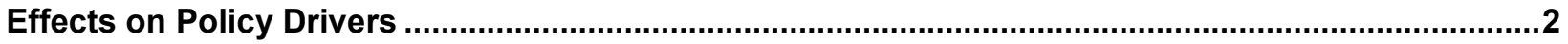

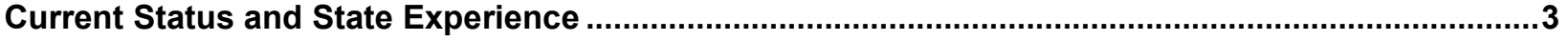

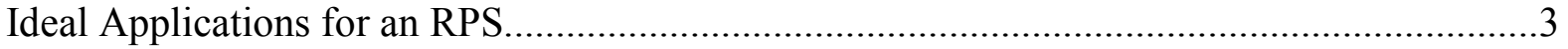

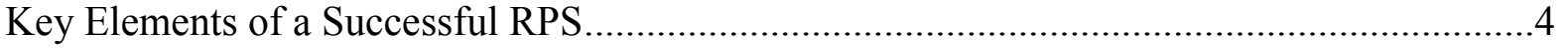

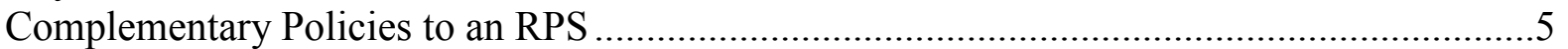

Alternatives to an RPS: State Transmission Authorities .................................................6

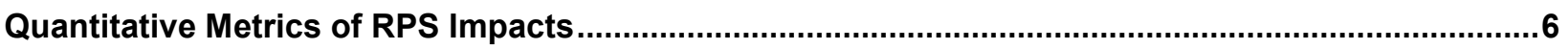

Trends in Selected RPS States ............................................................................... 9

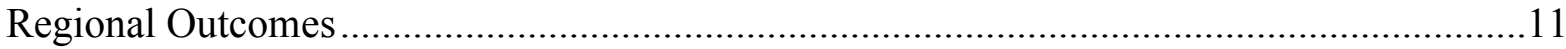

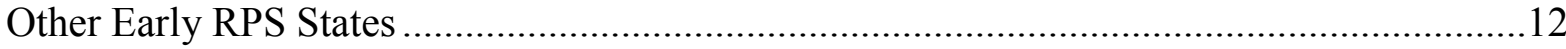

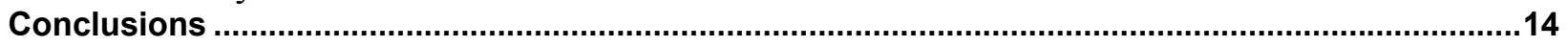

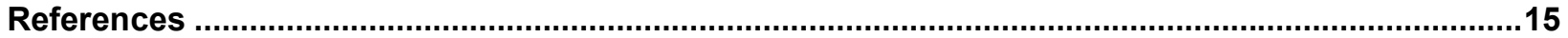




\section{SCEPA Project Background}

The State Clean Energy Policies Analysis (SCEPA) project is supported by the Weatherization and Intergovernmental Program within the Department of Energy's Office of Energy Efficiency and Renewable Energy. This project seeks to quantify the impacts of existing state policies, and to identify crucial policy attributes and their potential applicability to other states. The goal is to assist states in determining which clean energy policies or policy portfolios will best accomplish their environmental, economic, and security goals. Experts from the National Renewable Energy Laboratory (NREL) and Interenergy Solutions are implementing this work, with state officials and policy experts providing extensive input and review. This report focuses on renewable portfolio standard (RPS) policies, which are being analyzed as part of this project. For more information on the SCEPA project, access NREL's Applying Technologies Web site at http://www.nrel.gov/applying_technologies/scepa.html.

\section{Introduction}

A renewable portfolio standard (RPS) is a mandate to increase the use of wind, solar, biomass, and other alternatives to fossil and nuclear electric generation. This paper provides a summary of the policy objectives that commonly drive the establishment of an RPS, the key issues that states have encountered in implementing an RPS, and the strategies that some of the leading states have followed to address implementation challenges. The factors that help an RPS function best generally have been explored in other analyses (for example, Cory and Swezey 2007; Wiser and Barbose 2008). This study complements others by comparing empirical outcomes (i.e., which RPS programs appear to correlate with the greatest renewable capacity growth), and identifying the policies that appear to have the greatest impact on results.

An important overall insight suggested by initial outcomes is that an RPS is not a stand-alone policy. State experience indicates that results depend on complementary policies, especially those relating to transmission. States with an RPS that have significantly increased use of renewable resources either have available transmission, or have developed strategies to build it. Similarly, some states that have not significantly increased renewable capacity despite having an RPS for several years have identified inadequate transmission as one of the main contributing factors.

The following sections summarize issues common to many RPS programs. Because state circumstances vary, the relative importance of each factor differs among states; but certain key issues tend to be consistently present in some form. After the general overview, the analysis looks at selected metrics for electric generation from 2001 to 2007, identifying RPS states where use of renewable energy resources has increased significantly, and groups of states where RPS outcomes suggest significant regional dynamics.

The paper then examines the key factors that seem to affect outcomes for states that have had an RPS long enough for results to be evident. The aim is not to review all aspects of RPS design in these states, nor to identify a universal recipe for a successful program. Instead, the focus is on the most critical issues faced by pioneer states and what these states did to address those issues. The intent is to extract practical lessons that may assist other states that are considering, or are in the midst of implementing, RPS programs of their own. 


\section{Effects on Policy Drivers}

The main policy drivers behind an RPS include environmental enhancement, economic development, and greater energy security (by way of reduced reliance on price-volatile electricgeneration fuels such as natural gas). Program design - particularly the eligibility of out-of-state resources, and policies to expand voluntary green power offerings - can affect the relative importance of some of these drivers. Table 1 summarizes the theoretical effect of an RPS on various energy-related policy drivers.

Table 1. RPS Effects on State Policy Drivers

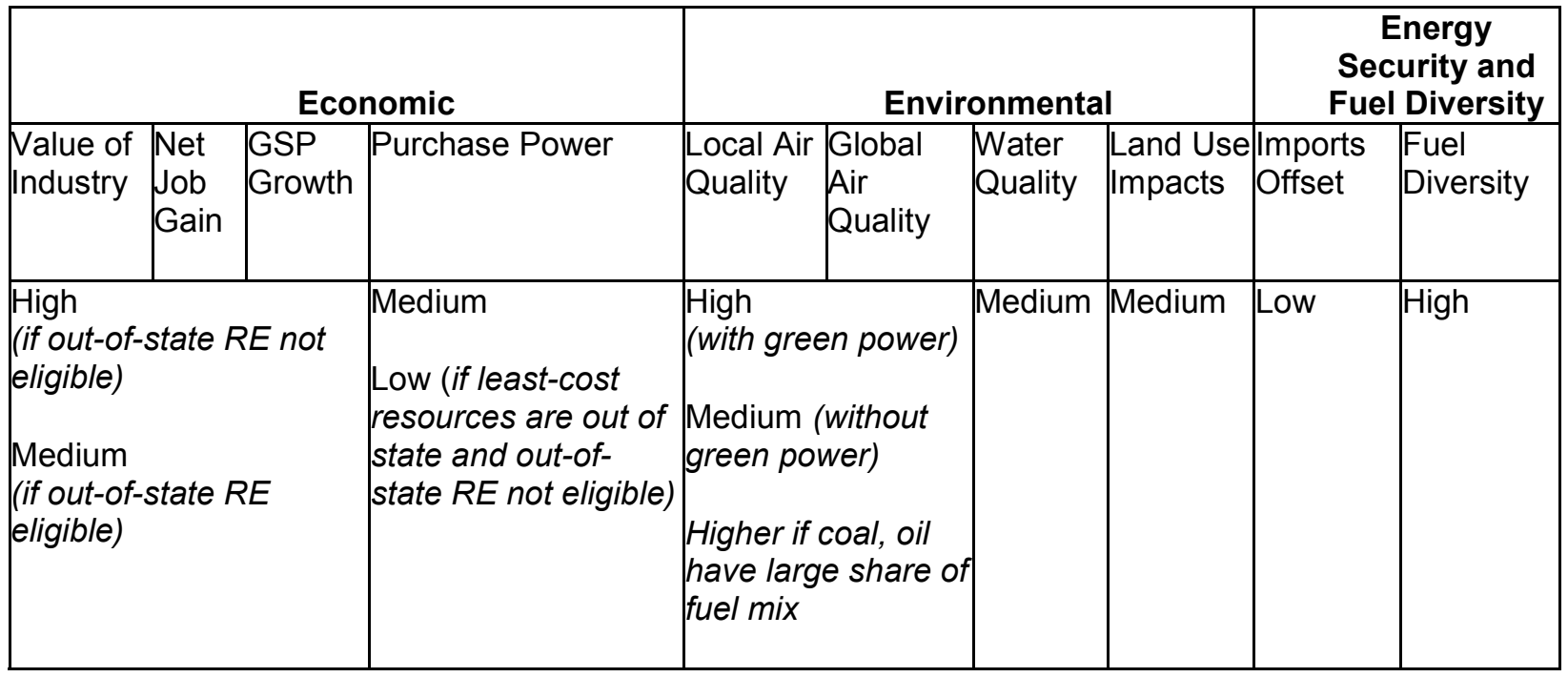

Reliably quantifying how much an RPS affects these drivers is problematic, however. Progress is not simply a function of implementing an RPS; ultimately, it's measured by whether the policy puts more renewable energy capacity on the grid. Even when a state's renewable energy capacity base increases, it may be incorrect to attribute all of a state's renewable energy growth solely to the existence of an RPS without accounting for interactions with other policies. Indeed, a number of states without an RPS have added considerable amounts of renewable capacity, outpacing some states that have had an RPS for years.

Assuming that an RPS works as intended, the economic development benefits can vary by state depending on how property taxes, income taxes, and excise taxes figure into the state's fiscal mix. ${ }^{1}$ The U.S. Department of Energy and NREL, through the Wind Powering America program, have published economic development studies for 12 states, examining the potential local benefits of renewable energy development (Wind Powering America 2008). A study of

\footnotetext{
${ }^{1}$ A comprehensive assessment was beyond the scope of this analysis, but anecdotal results are indicative of what can happen. The West Texas community of McCamey, where Texas' first wind boom took place in 2001 and 2002, is one example. In 2000, the local property tax base funding the McCamey Independent School District was just more than $\$ 328$ million in total assessed valuation. By 2006, with $760 \mathrm{MW}$ of new wind power in operation on nearby mesas, the tax base had increased by more than $\$ 1$ billion. In addition, taxable sales receipts in the area doubled from 2002 to 2005. See School and Appraisal Districts' Property Value Study, various years (available at http://www.cpa.state.tx.us/taxinfo/proptax/).
} 
Pennsylvania, for example, found that if an RPS succeeded in increasing renewable energy use to $10 \%$ of total electricity demand by 2025 , the impact on jobs, income, and economic output would be significantly larger than what would be expected if load growth and unit retirements during that same time were met by fossil fuel expansion. ${ }^{2}$

State policy makers may need to prioritize between local economic growth and minimizing ratepayer impacts if the most cost-effective renewable resources are in a neighboring state. Extending RPS eligibility to out-of-state resources can reduce ratepayer impacts, but it involves letting another state realize the local economic development benefits.

If environmental improvement is a particularly strong driver, policy makers may consider integrating an RPS mandate with policies to promote voluntary green power purchases. Such a strategy can augment the overall demand for renewable energy, which (in a normal commodity market) increases investment.

\section{Current Status and State Experience}

By 2004, 12 states had an RPS requirement, although the structure of these requirements varied widely. Some represented aggressive growth, while others constituted little change from the status quo. Some states placed the requirement only on specific utilities; some established minimum quotas for all providers in a competitive market. By early 2008, 25 states and Washington, D.C., had an RPS (listed in Table 2, at the end of the report), and many of the early RPS states had increased their goals.

\section{Ideal Applications for an RPS}

An RPS is best suited to states that know where their most cost-effective renewable resources are, and have a strategy for getting those resources to market.

Natural-resource endowments differ, and various renewable energy technologies differ in cost; these factors affect what an RPS design needs in order to achieve the best possible outcome at the least cost.

Consequently, an RPS can work in any regulatory structure, from traditional cost-of-service regulation to competitive restructuring. The regulatory environment affects how an RPS is implemented, but need not constrain what it can accomplish.

If a state does not have its own abundant, accessible, low-cost resources, achieving the ideal will involve policies to ensure that the regional transmission system is sufficiently robust to move renewable power from resource-rich areas to the state's load centers. This also may depend on the existence - or the creation — of multistate institutions to coordinate transmission planning and expansion.

\section{Key Elements of a Successful RPS}

Outcomes for the RPS mandates that have been around the longest suggest that two external factors have the most impact on what an RPS can accomplish on a large scale: available

\footnotetext{
${ }^{2}$ NREL's Job and Economic Development Impact (JEDI) tool provides state and local officials with a user-friendly tool to estimate potential benefits particular to their areas. See http://www.nrel.gov/analysis/jedi/.
} 
resources (e.g., wind, solar radiation, geothermal potential, or biomass stocks); and available transmission capacity.

Both factors have a bearing on the cost-effectiveness of in-state resources relative to regional resources, which also can affect program design and implementation. If a state has sufficient developable resources within its own jurisdiction, then attainment of its RPS requirement primarily is a matter of procurement, resource planning, and transmission decisions under the guidance of the state's utility regulators.

If neighboring states have more cost-effective resources, however, maximizing RPS results may depend on regional coordination. This is especially important for states that are part of the same regional transmission organization (RTO), where generation resources are dispatched on a leastcost basis without regard to state boundaries. RPS coordination can create a larger seamless demand for renewable energy, and larger markets tend to be more competitive. Lack of coordination, on the other hand, can fragment demand and place one or more states at a competitive disadvantage.

The following program elements take on greater importance if renewable resources are regionally dispersed and the state shares a transmission system with its neighbors.

- Qualifying out-of-state resources. If neighboring states share a transmission system, a substantial amount of power will cross state borders as part of normal grid operations. This aspect presents policy makers with a threshold decision about RPS design: How closely should the program follow the way power flows on the grid physically? Expanding RPS eligibility to include resources that are likely to contribute to power flows into the state can ensure that the program accounts for normal cross-border power flows. Regional resource qualification allows a broader geographic space for load-serving entities to find the least-cost options for meeting an RPS requirement. ${ }^{3}$

- A renewable energy credit (REC) tracking system. Tracking power flows in real time from a given generator to a given demand point is extremely complicated, data-intensive, and inconsistent with how the grid actually works. Power is managed as a regional pool of generation, with units ramped up or down minute-by-minute so that the sum of generation always matches the sum of regional demand. A REC tracking system can simplify the energy accounting required for an RPS, significantly reducing the administrative burden of coordinating different state requirements, and significantly reducing transaction costs for sellers and buyers of renewable power. Monitoring RPS compliance also is less burdensome with a REC tracking system. An RPS requirement that is met by qualified RECs can be verified electronically by regulators in a matter of seconds, and can avoid the need for lengthy compliance dockets.

Regardless of whether the program focus is regional or limited to in-state resources, costmitigation measures and compliance enforcement can have a bearing on success.

- $\quad$ Cost-control provisions. A no-fault alternative compliance payment (ACP), price cap, or cost benchmark can affect the ability of an RPS to attract investment in renewable energy

\footnotetext{
${ }^{3}$ Some legal scholars have suggested a possible constitutional prohibition against excluding out-of-state resources from RPS eligibility, but to date the argument has not been tested in court (see Eisen 2005).
} 
resources. The threshold decision for policy makers is how to balance two competing objectives: minimizing ratepayer impact, and maximizing the state's ability to attract investment in renewable energy capacity. A cap that is benchmarked close to the cost of conventional power often risks limiting project revenues constantly and predictably, which may cause developers and investors to avoid that state in favor of other places that pose less of an economic risk. On the other hand, a cap that does not take effect except under extraordinary circumstances is not an investment barrier. Many RPS statesincluding Texas, which leads the nation in renewable energy capacity growth - have balanced price protection and investment stimulation by setting their various cost-limiting safeguards to about $\$ 50$ per megawatt hour (MWh). However, set-aside requirements for specific technologies such as photovoltaic solar often have separate and higher caps.

- Enforcement. Penalties for noncompliance can affect RPS success where electricity markets have been restructured and entities with an RPS obligation set their own prices and manage their own costs. Under cost-of-service regulation, however, the ability of a regulated entity to comply is often linked to state decisions affecting transmission approval and cost recovery, making "compliance" a matter managed by the regulatory agency across various related proceedings.

\section{Complementary Policies to an RPS}

As mentioned previously, an RPS can achieve its goal easier and at less cost if it is consistent with other supporting policies, such as the following.

- $\quad$ Resource assessment. Mapping out where the best resources are located can improve both the effectiveness of an RPS and the ability to develop its renewable energy resources at the least cost to ratepayers. Texas, Colorado, Arizona, and California have initiated detailed assessments based on geographic information system (GIS) analysis, and other states are considering similar measures. A state-initiated assessment may not be necessary if developers and policy makers already know where the best resources are, if transmission access is already available, and if development is already occurring. Even if resource areas are generally known, however, a more precise measure of their development potential can help regulators form more cost-effective infrastructure strategies.

- Transmission access. If sufficient transmission capability does not exist between load centers and places where renewable resources exist, infrastructure expansion policies need to accompany an RPS if the latter is to be successful. The leading example is Texas, which passed legislation waiving certain "used and useful" criteria for transmission serving Competitive Renewable Energy Zones designated by the Texas Public Utilities Commission (PUC). In contrast, the lack of available transmission capability has compromised Nevada's ability to use its abundant geothermal resources in achieving its RPS goals.

- Voluntary green power. An RPS requirement can be designed so that it stimulates surplus supply, which will be available to meet additional, voluntary demand for renewable power. In fact, a 2007 NREL report showed that customer participation rates in 2006 utility green power programs were statistically higher on average in states with an RPS than those without (Cory and Swezey 2007). For this to happen, the state must coordinate 
consumer protection rules and RPS design to prevent "double counting," i.e., crediting the same quantity of renewable power toward both a mandated RPS requirement and to green power purchased voluntarily by a customer. This model, which has been used by a number of states that have seen the greatest increase in renewable resource use, relies on an RPS goal that is high enough to convince investors that future demand will never fall below a predictable level, yet low enough to permit a surplus to develop.

- Financing support. Many RPS policies require specific, minimum support to help new projects secure financing, which can be critical. For example, 10 states require loadserving entities to sign long-term contracts (usually at least 10 years in length) to reduce the financial risk that renewable energy developers face. In New York and Illinois, state agencies centrally procure RECs to meet the RPS requirement. Nevada implemented a special ratepayer charge to protect payments to generators, while California exempted utilities until they had re-established their creditworthiness. All of these mechanisms lower investment risk, making it easier for the state to attract investment in resources to meet its RPS.

\section{Alternatives to an RPS: State Transmission Authorities}

If a state has abundant resources, little native load, and sufficient transmission infrastructure, an aggressive energy export strategy can attract significant renewable energy investment without an RPS. Non-RPS states such as Kansas, South Dakota, and Wyoming have established state transmission authorities empowered to build, own, and operate transmission lines on behalf of the state. New Mexico and Colorado have both an RPS and a state transmission authority.

To date, the efficacy of state transmission authorities as an alternative to an RPS appears to be limited to states endowed with large amounts of prime wind power resources. In some cases, the creation of such an authority has followed (not led) an initial surge of investment interest by wind power developers, as demonstrated by a large volume of requests to transmission utilities for interconnection studies.

\section{Quantitative Metrics of RPS Impacts}

The point of an RPS is to replace fossil fuel generation with generation obtained from renewable resources. Therefore, most straightforward measures of RPS effectiveness are the degree to which renewable energy capacity and generation have grown, and the degree to which fossil fuels have declined as a share of the state's electric-generation fuel mix. The correlation between these outcomes and an RPS is impossible to quantify with precision, due to differences in state circumstances, the newness of many state requirements, and the significant interaction effects of other policies. The approach taken in this analysis, therefore, is to identify states with outcomes above the U.S. average, identify which of these states have had an RPS in place long enough to have an effect, and examine the role of the RPS in the state's outcomes.

It should be noted that measuring outcomes is different from measuring an RPS program's success. For example, if a significant portion of a state's total RPS requirement is met by way of an ACP, the legal requirements may be satisfied even if the statutory goal is not achieved physically. Moreover, because the RPS level is determined independently by each state, based on its own domestic political and economic calculus, the same outcome may represent technical 
success in one state and technical underachievement in another. In some cases, states have revised their goals on the basis of experience with their initial goals. Because of these factors, and the need to draw consistent empirical comparisons across all states, this analysis does not consider success in relation to a state's own RPS goal, but instead relies on standard outcome metrics as its basis of comparison, without judging whether the outcome constitutes "success." Such evaluation is more properly done by the state itself against its own statutory requirements, and is beyond the scope of this study.

This analysis looked at annual data from 2001 through 2007 for the following outcome metrics: ${ }^{4}$

- Increase in renewable generating capacity (new megawatts per year);

- Increase in net generation from renewable energy resources (additional megawatt hours per year);

- Growth in renewable energy's share of in-state generation capacity (percentage point gain per year);

- Growth in renewable energy's share of in-state generation mix (percentage point gain per year); and

- Decline in generation from fossil fuel sources (coal, natural gas, and petroleum) as a share of the state's overall generation fuel mix.

Seven-year trends were calculated for each state to determine which RPS states were above the national average with respect to renewable energy use and offsetting generation from fossil fuels. Table 3 and Table 4 (at the end of the report) show the state outcomes. ${ }^{5}$

Next, states were analyzed together (by reliability region) to assess possible regional factors. Figure 1 and Figure 2 highlight the key national and regional trends. Renewable energy is a small but growing share of the national generation portfolio, but that trend is small compared to the growth in generation from natural gas. Given the volatility of natural gas prices, this national trend suggests that energy security (particularly price stability) likely will become an important policy driver for an RPS.

\footnotetext{
${ }^{4}$ Metrics were calculated using annual unit data for electric generation compiled by the Energy Information Administration. EIA Form 860 is a report of installed capacity submitted annually by plant owners; Form 861 is a report of electricity sales and revenues submitted annually by utilities and other providers; and Form 906/920 is a report of net generation and fuel consumption reported monthly by plant owners. For the purposes of this analysis, "renewable energy" aggregates the following EIA fuel categories: wind, geothermal, sun, wood and wood waste (solid and liquid), agricultural byproducts, other biomass, landfill gas, and new hydropower capacity.

${ }^{5}$ The trends include net generation data for 2007, which (as of this writing) are preliminary and subject to revision by EIA.
} 
Fuel mix for total U.S. electric generation

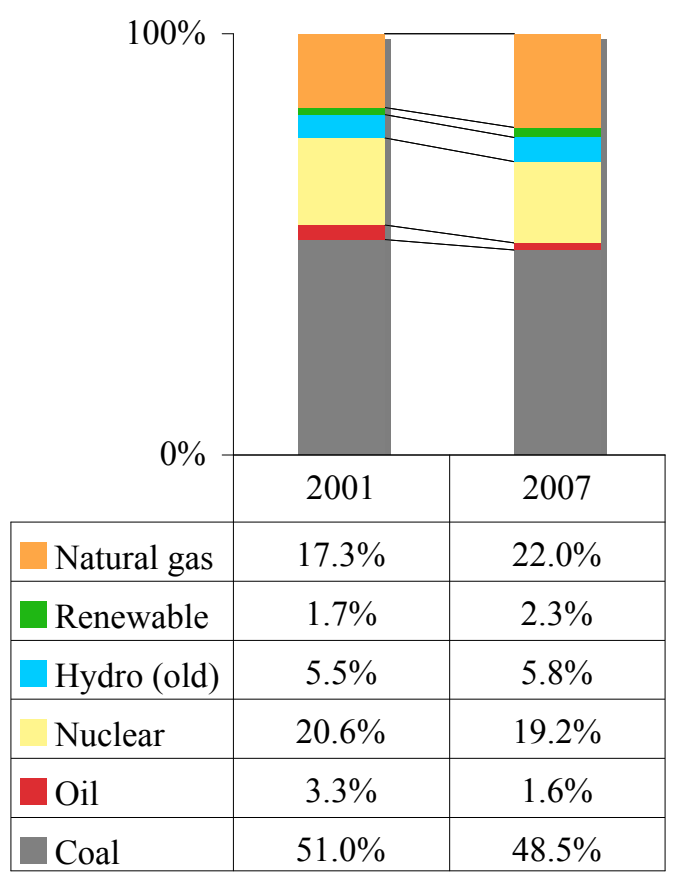

Annual change in U.S. fuel mix share

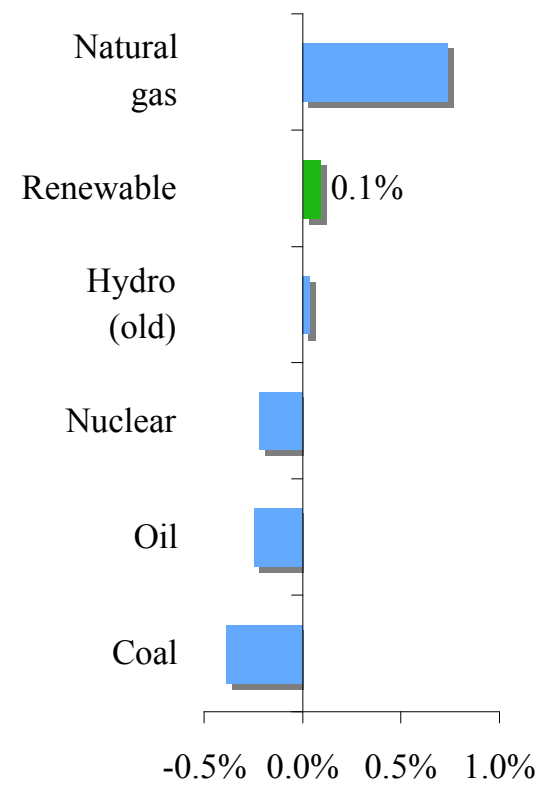

Annual change in share

Note: Hydroelectric capacity existing prior to 2001 is treated as a separate category. Newer hydro capacity and incremental additions to existing capacity are included as renewable.

Figure 1. National trends in electricity generation (2001-2007)

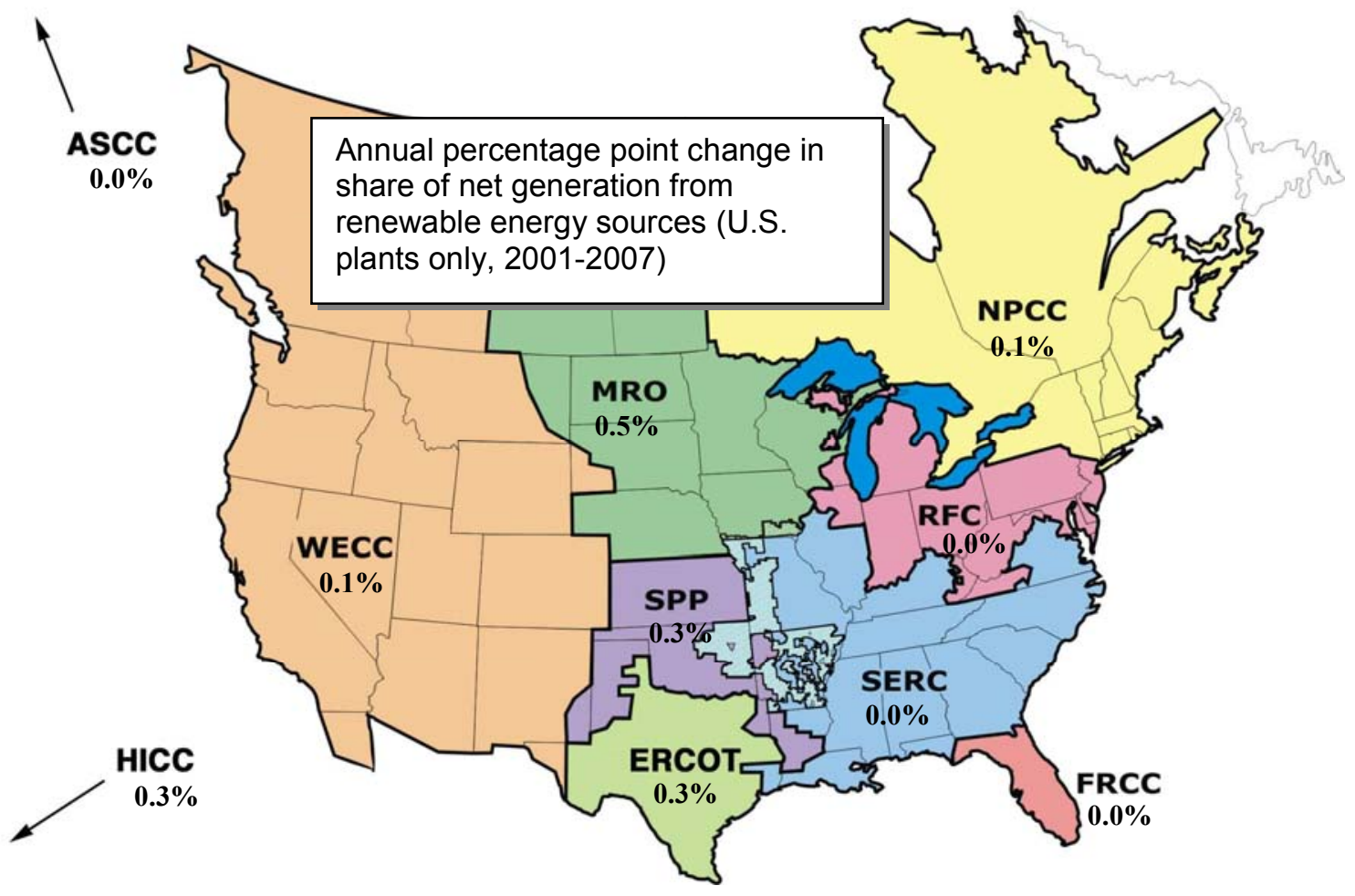

Figure 2. Growth in renewable energy utilization by NERC reliability region 
Fifteen states have exceeded the national average with respect to using more renewable energy and using less fossil fuel, as measured by annual changes in the composition of the generation fuel mix. Of these 15 states, 11 have an RPS: Colorado, Hawaii, Iowa, Maine, Minnesota, Montana, New Mexico, Nevada, Oregon, Texas, and Washington. All five of the states where the use of fossil fuels is decreasing - Maine, Washington, Montana, Iowa, and New Mexico- have an RPS.

The regional trends indicate significant renewable energy growth along the Great Plains and in Hawaii, little overall growth in the East, and moderate overall growth in the West and Northeast. ${ }^{6}$ An important factor in the West is the drought-related fluctuation in generation from major hydroelectric facilities (which, in this analysis, are treated as a distinct generation category apart from other renewable resources). Changes in production from hydropower significantly affect all other resource categories' share of the regional generation fuel mix.

\section{Trends in Selected RPS States}

Against these national and regional trends, the greatest increases in renewable energy capacity expansion and use are found in Iowa, Minnesota, New Mexico, and Texas - states with some of the longest-standing RPS requirements. Texas leads the nation in terms of absolute growth. Iowa, New Mexico, and Minnesota each added significantly more capacity and generated significantly more electricity from renewable sources than did states with significantly larger demand.

Texas. Texas has added 5.5 gigawatts $(\mathrm{GW})$ of new renewable capacity since its RPS began in 2002. Net generation from renewable sources is increasing at a rate of more than 1 terawatt hour (TWh) per year. Despite the simultaneous addition of a large amount of generation fueled by natural gas, Texas has managed to increase renewable energy's share of the state fuel mix from $0.6 \%$ in 2001 to $2.3 \%$ in 2007 .

The state, historically driven by an oil- and gas-development economy, implemented its RPS in conjunction with legislation to restructure the electric industry as a competitive market. The requirement was set as a capacity goal ( $2 \mathrm{GW}$ of new capacity by 2009 , later increased to $5 \mathrm{GW}$ by 2015), and annual requirements were assigned proportionately to retail electric providers and the few remaining investor-owned utilities. Wind developers, in particular, have responded to the open-access transmission policies that accompanied competitive restructuring. Both the RPS requirement and electricity labeling laws were designed to encourage retail green power as an additional source of demand for renewable energy (Hurlbut 2008).

Nevertheless, renewable energy outcomes for Texas have been constrained by transmission. In the Electric Reliability Council of Texas (ERCOT) RTO, the initial wave of wind power development in 2001-2002 was more than existing transmission lines could handle. Curtailments ordered by ERCOT to prevent overloading degraded the overall capacity factor of wind resources to $27 \%$, compared to a technical potential of about $40 \%$. In addition, the Texas Panhandle - where the state's best wind resources are located — saw limited wind power development initially because the states that are part of the Southwest Power Pool (the grid serving the Panhandle) had not yet addressed transmission planning questions that were critical

\footnotetext{
${ }^{6}$ The geography of NERC reliability regions has changed since 2001 . For consistency, historical observations for individual units were recoded to reflect their 2007 NERC regions. Units operating in 2001 that were retired before 2007 were assigned to the 2007 region of their operating companies (or successors).
} 
to wind power. Texas devised its Competitive Renewable Energy Zones (CREZ) policy (mentioned in the previous section discussing complementary policies) to respond to the transmission challenges. The Texas Public Utility Commission (PUC) approved a CREZ transmission development plan in July 2008 that would accommodate up to $18.5 \mathrm{GW}$ of wind power.

Iowa. In Iowa, net generation from renewable resources increased from $567 \mathrm{GWh}$ in 2001 to 2.9 TWh in 2007. Fossil fuels have been declining as a share of the state's generation fuel mix at a rate of 0.7 percentage points per year.

Iowa also had a capacity goal; but, unlike Texas, the statute included no fixed timetable. Nevertheless, Iowa authorities officially declared the requirement satisfied in November 2007 . $^{7}$ Although the law required only $105 \mathrm{MW}$, the state had more than 1,270 MW of wind power by the beginning of 2008. However, Iowa officials chose not to enact a larger RPS as a next step. Noting that the resulting revenues could provide a net benefit to Iowa ratepayers, the state utilities board instead laid the groundwork for a strategy to export Iowa wind power to meet renewable energy demand in other states that were part of the Midwest Independent System Operator (MISO) RTO. First, the board initiated an inquiry into whether the state's two major utilities should participate in the REC tracking system serving the MISO region. Second, the board designated specific generating units owned or controlled by the two utilities to be the resources satisfying 105 MW RPS requirement. RECs from all other units would be eligible to participate in the Midwest Renewable Energy Tracking System (M-RETS), being readily available to meet demand anywhere in the MISO region without resulting in double counting.

New Mexico. In New Mexico, net generation from renewable resources increased from zero to 1.3 TWh between 2001 and 2007. The state is exceeding its overall RPS requirement by a large margin: Its three largest utilities generated half again as much electricity from renewable resources as they needed to meet their 2006 RPS requirements.

The RPS also has a diversification requirement that utilities are supposed to meet by 2011 . Of the total mandate, no less than $20 \%$ must come from solar power, and no less than $10 \%$ must come from a renewable technology other than wind or solar. Despite these goals, nearly all of the state's eligible renewable generation in 2006 came from wind. RPS rules allow for waiving the diversity requirement on a number of grounds - cost caps being key — but the utility would have to make up the difference by procuring more electricity from other renewable resources. ${ }^{8}$

New Mexico has also implemented laws to facilitate transmission expansion, and was the first state to create a transmission authority in addition to having an RPS. The New Mexico Renewable Energy Transmission Authority participates in regional transmission planning groups, and is empowered to initiate its own projects. ${ }^{9}$ Regional transmission proposals under discussion would connect areas containing the state's best potential for geothermal and

\footnotetext{
7 “Order Approving Facilities and Associated Capacities, Adopting Requirements for M-RETS Participation, and Requiring Report," In Re: Interstate Power and Light Company and Midamerican Energy Company, Docket Number AEP-07-1 (November 21, 2007)

${ }^{8}$ New Mexico Administrative Code, 17.9.572, "Renewable Energy for Electric Utilities."

${ }^{9}$ New Mexico Renewable Energy Transmission Authority Act (House Bill 188), 2007.
} 
concentrating solar power, which would facilitate achievement of the state's diversification requirement.

Minnesota. Renewable energy is gaining as a share of the state's generation mix by about 0.5 percentage points annually, while the state's use of fossil fuel is decreasing by a slightly greater amount. By 2007, renewable resources accounted for 5.9\% of the electricity generated in Minnesota.

Until recently, Minnesota's renewable energy mandate applied only to the state's largest utility (Xcel Energy). All others were required to make a "good-faith effort" to achieve lower goals, and the Minnesota PUC was authorized to investigate a utility's good-faith effort on a regular basis. In 2007, the requirement was broadened to become a generally applicable RPS, although the ultimate requirement for Xcel (30\% of sales by 2020) is more rigorous than for other utilities $(25 \%$ by 2025$)$.

\section{Regional Outcomes}

New England and New York. Renewable energy outcomes in New England and New York reflect strong intra-regional dynamics. These states share the same electric reliability region and two regional transmission organizations with significant wholesale power exchanges. The aggregated picture reflects little overall growth in renewable energy's share of the regional fuel mix between 2001 and 2007. However, the geographic distribution of renewable and fossil fuel generation shifted significantly. Fossil fuel generation has declined in Maine, New York, and Vermont. The difference has been offset by increased fossil fuel use in New Hampshire, Connecticut, Rhode Island, and Massachusetts. New York accounted for the lion's share of the region's renewable energy growth, with smaller increases in Maine and Vermont.

The effect of RPS policies on the geographic shift, however, is unclear. New York, Massachusetts, and Connecticut all have an RPS. But, in both of the latter, use of fossil fuels grew faster than the use of renewables.

Electricity suppliers in Massachusetts have been in technical compliance with RPS requirements, but only two-thirds of the compliance is due to actual procurement of renewable resources (DOER 2007). Suppliers exercised the option for no-fault alternative compliance payments for one-third of their 2005 obligations, equivalent to $368 \mathrm{GWh}$ of electricity. Massachusetts' RPS shortfall largely reflects a regional shortage of new renewable capacity; although, during the 2001-2006 time frame, the state added some new renewable capacity in the form of biomass and landfill methane facilities.

The Midwest. The region with the most robust renewable energy growth is the Upper Great Plains. Iowa and Minnesota, which had renewable energy requirements at an early stage, account for two-thirds of the renewable energy growth in the region. Above-average outcomes for these two early RPS states have been driven by wind power-Iowa and Minnesota account for $18 \%$ of installed U.S. wind capacity (AWEA 2008). At the same time, Illinois and Wisconsin are increasing their use of fossil fuels for power generation. These are the two largest states for total power generation in the region. Renewable energy's share of the Illinois fuel mix has been mostly unchanged since 2001; while, in Wisconsin the share has increased slightly from $1.7 \%$ to $2.1 \%$. 


\section{Other Early RPS States}

Outcomes for three other early RPS states - New Jersey, California, and Nevada - are notable because of the obstacles they have encountered implementing their requirements. Generation from renewable sources in New Jersey actually declined between 2001 and 2007. Fossil fuel generation has decreased even faster, however, indicating a growing overall reliance on power flowing into the state from elsewhere in the PJM Interconnection grid area.

Providers cite difficulty obtaining sufficient RECs to meet their RPS obligations. The staff of the New Jersey Board of Public Utilities said possible reasons for the shortage included, among other factors:

- the establishment of new RPS requirements in several other states in the PJM Interconnection, which has increased competition for the renewable capacity added in the region since 2001;

- the option provided by other states (but not New Jersey) to "bank" RECs for two and sometimes three years;

- the choice of several small facilities not to have their generation metered by PJM, resulting in the disallowance of those facilities' energy for providing RPS-compliant RECs;

- growth in the use of RECs for the voluntary market; and

- insufficient growth in new construction of renewable energy generation facilities (N.J. Board of Public Utilities 2008).

Development of new renewable generation is proceeding slowly in California, despite having an aggressive RPS goal. In 2007, for example, only 114 MW of new RPS-eligible capacity came online, and most of it was in Oregon. Barriers cited by the California PUC in its 2008 legislative report include transmission, permitting challenges, and developer inexperience, among other factors (Calif. PUC 2008).

To address the transmission issues, the state has initiated a Renewable Energy Transmission Initiative to identify the transmission projects needed to accommodate the state's renewable energy goals (CEC 2008). Once renewable energy zones and possible transmission corridors have been identified by the RETI study, candidate projects will go to the California PUC for review. The California PUC is also considering whether to authorize the use of tradable RECs for compliance with the RPS.

Nevada is using its existing geothermal capacity more - and its existing coal-fired capacity less - while increasing its use of imported power to meet its growing demand. Although it has significant potential for additional geothermal and solar power, Nevada has been challenged by its inability to move power from regions rich in geothermal potential to its largest load center, Las Vegas. In addition, Nevada utilities were greatly affected by the California energy crisis, which (among other consequences) hurt the utilities' credit ratings. New renewable generating plants that signed power purchase agreements with the utilities were unable to secure financing. 
Only after the state created a separate charge on customers' bills did investors feel confident that the utilities would pay renewable generators for their power.

In December 2007, an advisory committee on renewable energy transmission access delivered to Governor Jim Gibbons a report that mapped out the state's most developable resources and recommended the construction of transmission lines and collector systems to connect those resources to load (Nevada 2007). The report also identified geothermal and solar projects under development that, when connected to the grid, would double the state's non-hydro renewable energy generating capacity. 


\section{Conclusions}

There is no policy magic behind an RPS; simply having an RPS is no guarantee of more renewable capacity. Achieving an RPS goal depends on knowing where the most cost-effective renewable resources are, and how they are going to get to market. An RPS results in more capacity expansion when accompanied by complementary policies that will help achieve RPS goals, such as resource assessments, transmission expansion, and regional collaboration. As demonstrated by Texas and Iowa, an RPS mandate need not be high to work.

The effectiveness of an RPS in any particular state often depends on regional coordination. One effort toward such multistate collaboration is a new initiative by the Western Governors' Association to identify concentrations of renewable energy resources and to assess high-level regional transmission scenarios for connecting these zones to load. A similar multistate resource assessment in the Southeast — where only North Carolina has enacted an RPS - could help identify least-cost renewable energy strategies that would fully take regional factors into account.

One element of RPS design that merits further empirical analysis is the effect of safety cap mechanisms such as cost thresholds and alternative compliance payments. This would be especially useful to states considering a new RPS or increasing an existing one. Ratepayer impact is a criticism frequently raised by RPS opponents, and many states have responded by including provisions to prevent costs from escalating excessively. Issues addressed in such an analysis should include how frequently the price cap is triggered, the types of renewable resources involved, the effect on investment and development risk, and the magnitude of renewable energy's incremental cost relative to the price impact of natural gas volatility. 


\section{References}

American Wind Energy Association (AWEA). (2008). "U.S. Wind Energy Projects." Accessed 2008 at http://www.awea.org/projects/.

California Energy Commission (CEC). (2008). "California Renewable Energy Transmission Initiative Mission Statement," accessed March 19, 2008, at http://www.energy.ca.gov/reti/Mission_Statement.pdf.

California Public Utilities Commission (PUC). (2008) "Renewables Portfolio Standard Quarterly Report." January 2008.

Cory, K. S.; Swezey, B. G. (2007). "Renewable Portfolio Standards in the States: Balancing Goals and Implementation Strategies." 36 pp.; NREL Report No. TP-640-41409.

Eisen, J. (2005). "The Environmental Responsibility of the Regionalizing Electric Utility Industry," Duke Environmental Law \& Policy Forum, Vol. 15 (2005), pp. 295-314.

Hurlbut, D. (2008). "A Look behind the Texas Renewable Portfolio Standard - A Case Study," Natural Resources Journal, Vol. 48, winter 2008.

Massachusetts Department of Energy Resources (DOER). (2007). "Massachusetts Renewable Portfolio Standard: Annual RPS Compliance Report for 2005," February 20, 2007 (corrected August 23, 2007).

Nevada (State of). (2007). “Phase I Report,” Governor Jim Gibbons' Nevada Renewable Energy Transmission Access Advisory Committee, December 31, 2007.

New Jersey Board of Public Utilities. (2008). "In the Matter of the Renewable Portfolio Standards - Request for Board Action Regarding Renewable Energy Certificates." (January 31, 2008).

Wiser, R.; Barbose, G. (2008) "Renewable Portfolio Standards in the United States: A Status Report with Data through 2007," Lawrence Berkeley National Laboratory, April 2008. 
Table 2. States with a Renewable Portfolio Standard

\begin{tabular}{ll} 
State & $\begin{array}{c}\text { Year } \\
\text { effective } \\
\text { (last } \\
\text { amended) }\end{array}$ \\
\hline lowa & $1983(1997)$ \\
Minnesota & $1997(2007)$ \\
Connecticut & $1998(2007)$ \\
Maine & $1999(2007)$ \\
New Jersey & $2001(2006)$ \\
\hline Wisconsin & $2001(2006)$ \\
Massachusetts & 2002 \\
Texas & $2002(2005)$ \\
Arizona & $2002(2006)$ \\
Nevada & $2002(2006)$ \\
\hline New Mexico & $2002(2007)$ \\
California & $2003(2006)$ \\
Hawaii & $2004(2006)$ \\
Rhode Island & $2004(2006)$ \\
Colorado & $2004(2007)$ \\
\hline New York & 2005 \\
District of Columbia & 2005 \\
Maryland & $2005(2007)$ \\
Pennsylvania & $2005(2007)$ \\
Montana & 2006 \\
\hline Delaware & $2006(2007)$ \\
Washington & 2007 \\
Illinois & 2007 \\
New Hampshire & 2007 \\
Oregon & 2007 \\
North Carolina & 2008 \\
& \\
\hline
\end{tabular}

Note: North Dakota, Missouri, Utah, Vermont, and Virginia have non-mandatory state goals for generation from renewable energy resources. 
Table 3. State Trends in Generation from Renewable Energy, 2001-2007

\begin{tabular}{|c|c|c|c|c|c|c|c|}
\hline & $\begin{array}{c}\text { Capacity } \\
\text { added } \\
\text { (MW/yr) }\end{array}$ & & $\begin{array}{c}\text { Increase in } \\
\text { generation } \\
\text { (GWh/yr) }\end{array}$ & & $\begin{array}{c}\text { Annual } \\
\text { increase in } \\
\text { share of state } \\
\text { capacity }\end{array}$ & & $\begin{array}{c}\text { Annual } \\
\text { increase in } \\
\text { share of state } \\
\text { fuel mix }\end{array}$ \\
\hline TX & 341 & $\mathrm{TX}$ & 1,087 & NM & $1.4 \%$ & $\mathrm{ME}$ & $1.3 \%$ \\
\hline CA & 166 & $\mathrm{CA}$ & 375 & ND & $1.0 \%$ & IA & $0.7 \%$ \\
\hline MA & 150 & IA & 370 & IA & $0.8 \%$ & NM & $0.7 \%$ \\
\hline OK & 126 & OK & 364 & AK & $0.7 \%$ & MN & $0.5 \%$ \\
\hline IA & 125 & WA & 286 & $\mathrm{MN}$ & $0.6 \%$ & SD & $0.5 \%$ \\
\hline $\mathrm{AL}$ & 112 & $\mathrm{MN}$ & 278 & ID & $0.6 \%$ & OK & $0.5 \%$ \\
\hline NM & 107 & NM & 255 & $\mathrm{NE}$ & $0.5 \%$ & OR & $0.4 \%$ \\
\hline MN & 105 & OR & 215 & WY & $0.4 \%$ & $\mathrm{KS}$ & $0.3 \%$ \\
\hline NY & 98 & NY & 184 & KS & $0.4 \%$ & MT & $0.3 \%$ \\
\hline OR & 80 & SC & 161 & $\mathrm{TX}$ & $0.3 \%$ & ND & $0.3 \%$ \\
\hline WA & 73 & $\mathrm{KS}$ & 159 & OK & $0.2 \%$ & $\mathrm{CO}$ & $0.3 \%$ \\
\hline PA & 57 & $\mathrm{CO}$ & 147 & WV & $0.2 \%$ & $\mathrm{TX}$ & $0.3 \%$ \\
\hline ND & 55 & VA & 114 & MA & $0.2 \%$ & WA & $0.2 \%$ \\
\hline $\mathrm{CO}$ & 49 & PA & 99 & CT & $0.1 \%$ & $\mathrm{HI}$ & $0.2 \%$ \\
\hline KS & 49 & MT & 90 & VT & $0.1 \%$ & NV & $0.2 \%$ \\
\hline $\mathrm{NE}$ & 46 & ND & 89 & LA & $0.1 \%$ & WY & $0.2 \%$ \\
\hline GA & 44 & $\mathrm{IL}$ & 82 & $\mathrm{IL}$ & $0.1 \%$ & NE & $0.1 \%$ \\
\hline WV & 39 & $\mathrm{FL}$ & 74 & $\mathrm{HI}$ & $0.0 \%$ & MS & $0.1 \%$ \\
\hline WY & 35 & WY & 72 & $\mathrm{NC}$ & $0.0 \%$ & VA & $0.1 \%$ \\
\hline ID & 33 & MS & 67 & RI & $0.0 \%$ & SC & $0.1 \%$ \\
\hline LA & 32 & WI & 65 & $\mathrm{FL}$ & $0.0 \%$ & NY & $0.1 \%$ \\
\hline MT & 32 & WV & 64 & $\mathrm{DC}$ & $0.0 \%$ & $\mathrm{RI}$ & $0.1 \%$ \\
\hline $\mathrm{FL}$ & 29 & $\mathrm{KY}$ & 60 & $\mathrm{DE}$ & $0.0 \%$ & WI & $0.1 \%$ \\
\hline ME & 27 & NV & 58 & $\mathrm{OH}$ & $0.0 \%$ & WV & $0.1 \%$ \\
\hline IL & 27 & ME & 57 & IN & $0.0 \%$ & VT & $0.1 \%$ \\
\hline NC & 23 & NE & 46 & MT & $0.0 \%$ & $\mathrm{KY}$ & $0.1 \%$ \\
\hline WI & 19 & LA & 42 & NJ & $0.0 \%$ & MD & $0.0 \%$ \\
\hline TN & 18 & ID & 38 & TN & $-0.1 \%$ & LA & $0.0 \%$ \\
\hline NV & 15 & SD & 31 & WI & $-0.1 \%$ & ID & $0.0 \%$ \\
\hline CT & 14 & $\mathrm{HI}$ & 29 & KY & $-0.1 \%$ & $\mathrm{IL}$ & $0.0 \%$ \\
\hline VA & 13 & MD & 25 & MS & $-0.2 \%$ & PA & $0.0 \%$ \\
\hline$A Z$ & 8 & $\mathrm{Ml}$ & 20 & $\mathrm{AL}$ & $-0.2 \%$ & IN & $0.0 \%$ \\
\hline SC & 8 & IN & 17 & PA & $-0.2 \%$ & AK & $0.0 \%$ \\
\hline $\mathrm{OH}$ & 6 & VT & 17 & UT & $-0.2 \%$ & $\mathrm{OH}$ & $0.0 \%$ \\
\hline $\mathrm{NH}$ & 5 & AR & 17 & $\mathrm{MI}$ & $-0.2 \%$ & $\mathrm{FL}$ & $0.0 \%$ \\
\hline NJ & 4 & $\mathrm{OH}$ & 14 & NY & $-0.3 \%$ & CT & $0.0 \%$ \\
\hline $\mathrm{HI}$ & 2 & NC & 6 & MD & $-0.3 \%$ & MO & $0.0 \%$ \\
\hline VT & 1 & RI & 5 & WA & $-0.3 \%$ & $\mathrm{Ml}$ & $0.0 \%$ \\
\hline IN & 1 & MO & 3 & $\mathrm{MO}$ & $-0.3 \%$ & $\mathrm{DE}$ & $0.0 \%$ \\
\hline $\mathrm{RI}$ & 0 & MA & 2 & $\mathrm{CO}$ & $-0.3 \%$ & DC & $0.0 \%$ \\
\hline AR & 0 & CT & 2 & GA & $-0.3 \%$ & $\mathrm{NJ}$ & $0.0 \%$ \\
\hline AK & 0 & AK & 1 & SD & $-0.5 \%$ & $A Z$ & $0.0 \%$ \\
\hline DC & - & DE & 0 & VA & $-0.7 \%$ & $\mathrm{NC}$ & $0.0 \%$ \\
\hline DE & - & $D C$ & - & NV & $-0.7 \%$ & MA & $0.0 \%$ \\
\hline $\mathrm{KY}$ & (0) & UT & (1) & SC & $-0.7 \%$ & UT & $0.0 \%$ \\
\hline UT & (2) & NJ & (1) & AR & $-0.8 \%$ & AR & $0.0 \%$ \\
\hline MS & (6) & $\mathrm{NH}$ & (1) & CA & $-0.9 \%$ & CA & $-0.1 \%$ \\
\hline MI & (6) & $A Z$ & (2) & OR & $-0.9 \%$ & $\mathrm{TN}$ & $-0.1 \%$ \\
\hline MD & (13) & $\mathrm{AL}$ & (33) & $\mathrm{NH}$ & $-1.0 \%$ & $\mathrm{AL}$ & $-0.1 \%$ \\
\hline SD & (21) & $\mathrm{TN}$ & (61) & $A Z$ & $-1.0 \%$ & $\mathrm{GA}$ & $-0.2 \%$ \\
\hline \multirow[t]{2}{*}{$\mathrm{MO}$} & (58) & GA & (136) & $\mathrm{ME}$ & $-1.1 \%$ & $\mathrm{NH}$ & $-0.4 \%$ \\
\hline & & & & US & $0.1 \%$ & US & $0.1 \%$ \\
\hline
\end{tabular}


Table 4. State Trends in Generation from Fossil Fuels, 2001-2007

\begin{tabular}{|c|c|c|c|c|c|c|c|}
\hline & $\begin{array}{c}\text { Capacity } \\
\text { added } \\
\text { (MW/yr) }\end{array}$ & & $\begin{array}{c}\text { Increase in } \\
\text { generation } \\
\text { (GWh/yr) }\end{array}$ & & $\begin{array}{c}\text { Annual } \\
\text { increase in } \\
\text { share of state } \\
\text { capacity }\end{array}$ & & $\begin{array}{c}\text { Annual } \\
\text { increase in } \\
\text { share of state } \\
\text { fuel mix }\end{array}$ \\
\hline$\overline{A K}$ & -60 & $\mathrm{ME}$ & $-1,075$ & $\mathrm{NM}$ & $-1.4 \%$ & $\mathrm{ME}$ & $-3.4 \%$ \\
\hline ND & -15 & NY & -966 & ND & $-1.0 \%$ & WA & $-0.7 \%$ \\
\hline VT & -1 & MS & -879 & WY & $-0.5 \%$ & MT & $-0.7 \%$ \\
\hline ID & 5 & VA & -590 & IA & $-0.3 \%$ & IA & $-0.7 \%$ \\
\hline SD & 13 & $\mathrm{RI}$ & -273 & $\mathrm{KS}$ & $-0.2 \%$ & NM & $-0.7 \%$ \\
\hline $\mathrm{HI}$ & 31 & $\mathrm{NJ}$ & -213 & WV & $-0.2 \%$ & VA & $-0.5 \%$ \\
\hline MT & 37 & WA & -138 & MN & $-0.2 \%$ & MD & $-0.5 \%$ \\
\hline WY & 44 & MD & -103 & VT & $-0.1 \%$ & NY & $-0.5 \%$ \\
\hline DC & 124 & CA & -73 & AK & $-0.1 \%$ & $\mathrm{CO}$ & $-0.4 \%$ \\
\hline WV & 132 & SD & -57 & $\mathrm{DE}$ & $0.0 \%$ & NE & $-0.3 \%$ \\
\hline WA & 139 & $\mathrm{MI}$ & -24 & IN & $0.0 \%$ & $\mathrm{MN}$ & $-0.3 \%$ \\
\hline KS & 142 & DC & -10 & OK & $0.0 \%$ & $\mathrm{TX}$ & $-0.3 \%$ \\
\hline TN & 146 & VT & -5 & $\mathrm{DC}$ & $0.0 \%$ & $\mathrm{OH}$ & $-0.3 \%$ \\
\hline $\mathrm{RI}$ & 162 & AK & -2 & MT & $0.0 \%$ & $\mathrm{Ml}$ & $-0.3 \%$ \\
\hline NM & 171 & KS & -1 & ID & $0.1 \%$ & OK & $-0.3 \%$ \\
\hline $\mathrm{MO}$ & 197 & ND & 25 & KY & $0.1 \%$ & CA & $-0.3 \%$ \\
\hline ME & 207 & $\mathrm{HI}$ & 96 & UT & $0.1 \%$ & $\mathrm{HI}$ & $-0.3 \%$ \\
\hline OR & 225 & ID & 99 & TN & $0.2 \%$ & ND & $-0.2 \%$ \\
\hline $\mathrm{NE}$ & 226 & WY & 181 & $\mathrm{OH}$ & $0.2 \%$ & $\mathrm{NJ}$ & $-0.2 \%$ \\
\hline NC & 243 & $\mathrm{TN}$ & 195 & LA & $0.2 \%$ & $\mathrm{KS}$ & $-0.2 \%$ \\
\hline UT & 258 & $\mathrm{NE}$ & 213 & $\mathrm{NC}$ & $0.2 \%$ & WY & $-0.2 \%$ \\
\hline MN & 280 & MT & 225 & $\mathrm{TX}$ & $0.3 \%$ & WV & $-0.1 \%$ \\
\hline $\mathrm{NH}$ & 290 & OR & 230 & $\mathrm{NE}$ & $0.3 \%$ & VT & $-0.1 \%$ \\
\hline CT & 321 & $\mathrm{DE}$ & 250 & WA & $0.4 \%$ & UT & $-0.1 \%$ \\
\hline $\mathrm{NJ}$ & 393 & $\mathrm{IA}$ & 312 & MO & $0.4 \%$ & IN & $0.0 \%$ \\
\hline IA & 418 & MN & 315 & $\mathrm{HI}$ & $0.5 \%$ & $\mathrm{DE}$ & $0.0 \%$ \\
\hline DE & 478 & LA & 443 & SD & $0.5 \%$ & $\mathrm{DC}$ & $0.0 \%$ \\
\hline NV & 493 & NV & 615 & IL & $0.6 \%$ & LA & $0.0 \%$ \\
\hline MD & 505 & CT & 650 & WI & $0.7 \%$ & $\mathrm{NV}$ & $0.0 \%$ \\
\hline KY & 522 & NM & 670 & NJ & $0.8 \%$ & OR & $0.0 \%$ \\
\hline LA & 527 & $\mathrm{CO}$ & 676 & $\mathrm{Ml}$ & $0.8 \%$ & $\mathrm{MO}$ & $0.1 \%$ \\
\hline WI & 651 & UT & 845 & GA & $0.9 \%$ & MS & $0.1 \%$ \\
\hline $\mathrm{CO}$ & 712 & NC & 847 & $\mathrm{FL}$ & $0.9 \%$ & NC & $0.2 \%$ \\
\hline IN & 712 & AR & 868 & $\mathrm{CO}$ & $1.0 \%$ & MA & $0.2 \%$ \\
\hline MI & 791 & WI & 903 & MD & $1.1 \%$ & ID & $0.3 \%$ \\
\hline AR & 794 & MA & 1,188 & OR & $1.3 \%$ & KY & $0.4 \%$ \\
\hline VA & 932 & $\mathrm{KY}$ & 1,252 & $\mathrm{AL}$ & $1.3 \%$ & WI & $0.4 \%$ \\
\hline SC & 982 & WV & 1,319 & MA & $1.4 \%$ & $\mathrm{IL}$ & $0.4 \%$ \\
\hline MA & 1,068 & $\mathrm{NH}$ & 1,551 & VA & $1.6 \%$ & $\mathrm{RI}$ & $0.5 \%$ \\
\hline IL & 1,074 & SC & 1,557 & MS & $1.6 \%$ & AK & $0.6 \%$ \\
\hline OK & 1,081 & IN & 1,593 & NY & $1.7 \%$ & $\mathrm{TN}$ & $0.6 \%$ \\
\hline $\mathrm{OH}$ & 1,092 & $\mathrm{OH}$ & 2,030 & NV & $1.7 \%$ & PA & $0.6 \%$ \\
\hline MS & 1,195 & $\mathrm{IL}$ & 2,090 & $A R$ & $1.8 \%$ & CT & $0.7 \%$ \\
\hline $\mathrm{AL}$ & 1,324 & MO & 2,490 & PA & $1.8 \%$ & $\mathrm{FL}$ & $0.7 \%$ \\
\hline NY & 1,433 & $\mathrm{AL}$ & 2,593 & SC & $2.1 \%$ & SC & $0.7 \%$ \\
\hline GA & 1,434 & OK & 2,813 & CA & $2.2 \%$ & AR & $0.7 \%$ \\
\hline$A Z$ & 1,990 & $\mathrm{TX}$ & 3,705 & CT & $2.4 \%$ & $\mathrm{AL}$ & $0.9 \%$ \\
\hline TX & 2,152 & GA & 3,989 & RI & $2.6 \%$ & SD & $0.9 \%$ \\
\hline $\mathrm{CA}$ & 2,665 & PA & 4,038 & $A Z$ & $2.7 \%$ & $\mathrm{GA}$ & $1.1 \%$ \\
\hline PA & 2,763 & $A Z$ & 4,350 & ME & $2.8 \%$ & $A Z$ & $2.2 \%$ \\
\hline \multirow[t]{2}{*}{$\mathrm{FL}$} & 2,909 & $\mathrm{FL}$ & 6,509 & $\mathrm{NH}$ & $3.7 \%$ & $\mathrm{NH}$ & $3.0 \%$ \\
\hline & & & & US & $0.1 \%$ & US & $0.1 \%$ \\
\hline
\end{tabular}




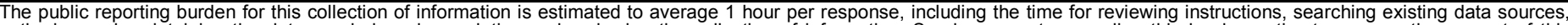

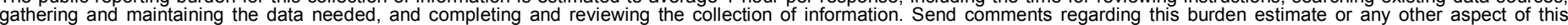

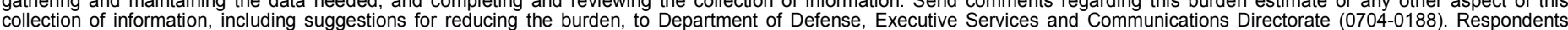

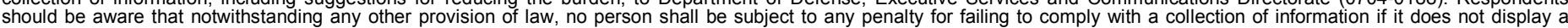

should be aware that notwithstanding

PLEASE DO NOT RETURN YOUR FORM TO THE ABOVE ORGANIZATION.

\begin{tabular}{l|l|l|l} 
1. REPORT DATE (DD-MM-YYYY) & 2. & REPORT TYPE & 3. DATES COVERED (FrOm - TO)
\end{tabular} July 2008

Technical Report

4. TITLE AND SUBTITLE

State Clean Energy Practices: Renewable Portfolio Standards

5a. CONTRACT NUMBER

DE-AC36-99-G010337

5b. GRANT NUMBER

5c. PROGRAM ELEMENT NUMBER

6. AUTHOR(S)

David Hurlbut

5d. PROJECT NUMBER

NREL/TP-670-43512

5e. TASK NUMBER

IGST.8300

5f. WORK UNIT NUMBER
7. PERFORMING ORGANIZATION NAME(S) AND ADDRESS(ES)

National Renewable Energy Laboratory

1617 Cole Blvd.

Golden, CO 80401-3393

9. SPONSORING/MONITORING AGENCY NAME(S) AND ADDRESS(ES)
8. PERFORMING ORGANIZATION

REPORT NUMBER

NREL/TP-670-43512

10. SPONSOR/MONITOR'S ACRONYM(S) NREL

11. SPONSORING/MONITORING AGENCY REPORT NUMBER

\section{DISTRIBUTION AVAILABILITY STATEMENT}

National Technical Information Service

U.S. Department of Commerce

5285 Port Royal Road

Springfield, VA 22161

\section{SUPPLEMENTARY NOTES}

\section{ABSTRACT (Maximum 200 Words)}

The State Clean Energy Policies Analysis (SCEPA) project is supported by the Weatherization and Intergovernmental Program within the Department of Energy's Office of Energy Efficiency and Renewable Energy. This project seeks to quantify the impacts of existing state policies, and to identify crucial policy attributes and their potential applicability to other states. The goal is to assist states in determining which clean energy policies or policy portfolios will best accomplish their environmental, economic, and security goals. For example, a renewable portfolio standard (RPS) mandates an increase in the use of wind, solar, biomass, and other alternatives to fossil and nuclear electric generation. This paper provides a summary of the policy objectives that commonly drive the establishment of an RPS, the key issues that states have encountered in implementing an RPS, and the strategies that some of the leading states have followed to address implementation challenges. The factors that help an RPS function best generally have been explored in other analyses. This study complements others by comparing empirical outcomes, and identifying the policies that appear to have the greatest impact on results.

\section{SUBJECT TERMS}

energy efficiency; renewable energy; policy; state policy; stakeholder drivers; economic development; environmental; energy security; renewable portfolio standards; RPS

\begin{tabular}{|c|c|c|c|c|}
\hline \multicolumn{3}{|c|}{ 16. SECURITY CLASSIFICATION OF: } & \multirow{2}{*}{$\begin{array}{l}\text { 17. LIMITATION } \\
\text { OF ABSTRACT } \\
\text { UL }\end{array}$} & \multirow{2}{*}{$\begin{array}{l}\text { 18. NUMBER } \\
\text { OF PAGES }\end{array}$} \\
\hline $\begin{array}{l}\text { a. REPORT } \\
\text { Unclassified }\end{array}$ & $\begin{array}{l}\text { b. ABSTRACT } \\
\text { Unclassified }\end{array}$ & $\begin{array}{l}\text { c. THIS PAGE } \\
\text { Unclassified }\end{array}$ & & \\
\hline
\end{tabular}

19a. NAME OF RESPONSIBLE PERSON

19b. TELEPHONE NUMBER (Include area code) 